ИЗВЕСТИЯ АКАДЕМИИ НАУК ЭСТОНСКОИ ССР. ТОМ 32. ГЕОЛОГИЯ. 1983, № 3

\title{
ДОЧЕТВЕРТИЧНЫЕ ПОВЕРХНОСТИ ВЫРАВНИВАНИЯ СЕВЕРО-ЗАПАДА ВОСТОЧНО-ЕВРОПЕИСКОЙ РАВНИНЫ
}

Восточно-Европейская равнина испытала в мезокайнозое несколько этапов расчленения и выполаживания, вследствие чего здесь сформировалась серия разновозрастных поверхностей выравнивания (Мещеряков, 1965; Горелов, 1974; Карта поверхностей..., 1971). На северозападе Восточно-Европейской равнины выделение дочетвертичных поверхностей выравнивания представляет определенные трудности, обусловленные длительным континентальным развитием этой территории (с конца палеозоя), ограниченным распространением мезокайнозойских (кроме четвертичных) пород и наличием сплошного покрова ледниковых отложений.

Для выделения погребенных поверхностей на северо-западе Восточно-Европейской равнины использован комплекс геолого-геоморфологических методов, важнейшими из которых являются анализ поверхности дочетвертичных пород (рисунок), кровли палеогеновых, допалеогеновых и доюрских пород, изучение их соотношений с покрывающими и подстилающими отложениями (Исаченков, 1964; Можаев, 1973; Шляупа, 1973). Наиболее достоверные выводы о дочетвертичных поверхностях выравнивания получены на левобережье Верхнего Поднепровья, в Южной Прибалтике и Белоруссии, где распространены коррелятные им отложения. По мере удаления от зоны распространения мезозойских, палеогеновых и неогеновых отложений достоверность выделяемых палеогеоморфологических уровней уменьшается. Особенно осторожно следует подходить к их выделению в Эстонии, Латвии и на северо-западе РСФСР, где доледниковый рельеф в плейстоцене был в значительной степени преобразован процессами экзарации (Исаченков, 1975).

\section{Дочетвертичные поверхности выравнивания}

В центральных и западных районах Восточно-Европейской равнины на поверхности палеозойских пород выделяются эрозионные ложбины глубиной до 20-60 м, заполненные континентальными (внизу) и морскими средне- и верхнеюрскими отложениями (Даньшин, 1927; Погуляев, 1955; Геология СССР, 1971). К северу от современной границы распространения морских верхнеюрских отложений встречаются континентальные верхнеюрские отложения, представленные в Смоленской области серыми глинами с включениями песка и углистого материала. Все эти данные свидетельствуют о том, что в мезозое на рассматриваемой территории выделялся полный геоморфологический цикл, включавший этапы расчленения и выполаживания, завершившиеся формированием полигенетической поверхности выравнивания. В Подмосковье, Южной Прибалтике и Белоруссии в это время располагалась морская аккумулятивная равнина, которая к северу и северо-западу сменялась 


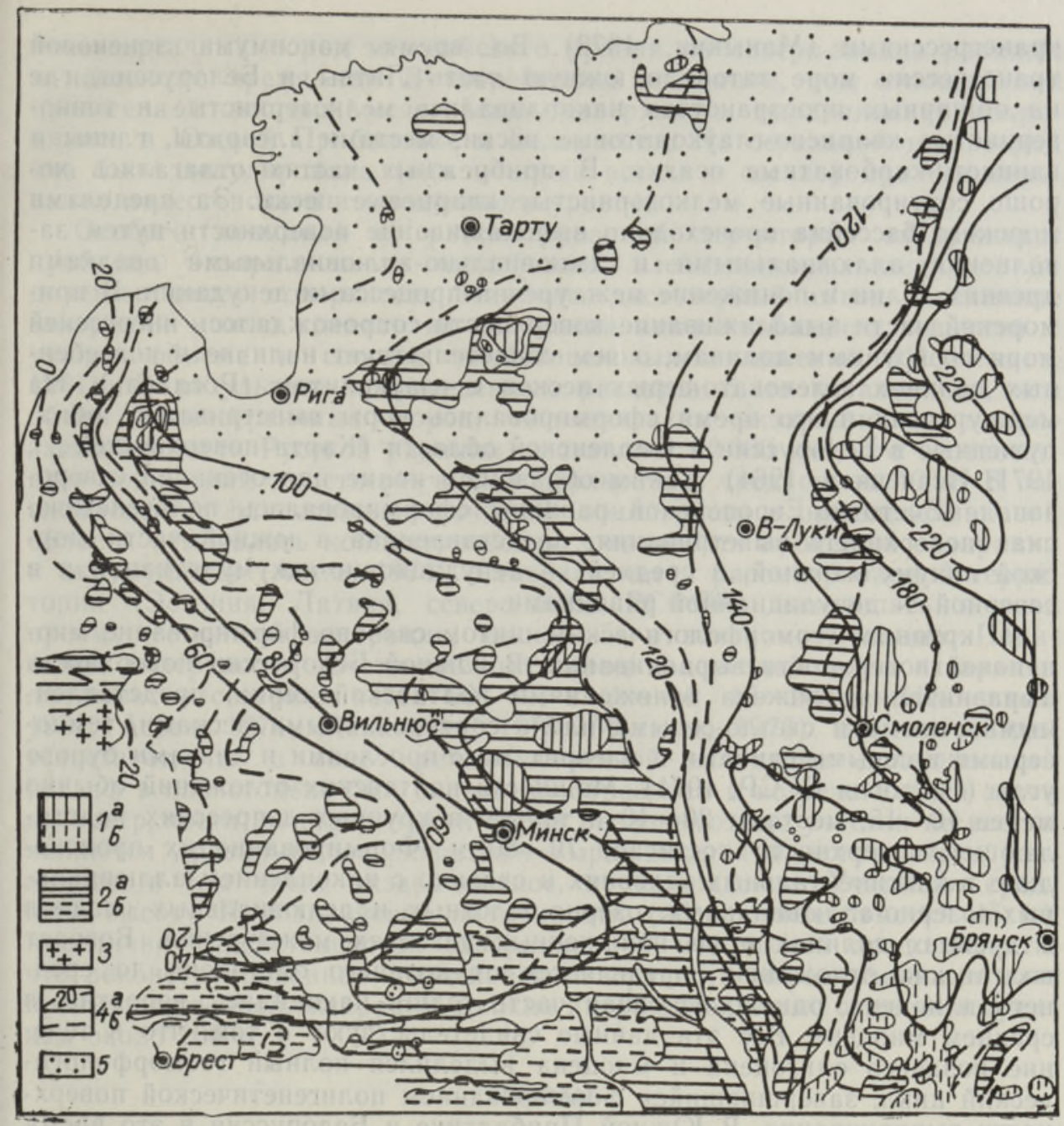

Схема дочетвертичных поверхностей выравнивания. Условные обозначения: 1 - поверхность выравнивания палеогенового времени, $a$ - денудационные, б - аккумулятивные равнины; 2 - поверхности выравнивания миоценового времени, $a$ - денудационные, б - аккумулятивные равнины; 3 - поверхность выравнивания плиоценового времени; 4 - изолинии деформаций палеогеновой $(a)$ и миоценовой (б) поверхностей выравнивания (в Южной Белоруссии деформации палеогеновой поверхности показаны на участках, находящихся в погребенном состоянии под миоценовыми осадками); 5 - дочетвертичная поверхность, сильно. преобразованная плейстоценовой экзарацией.

денудационно-аккумулятивной, а затем денудационной равнинами. Общее выполаживание поверхности продолжалось и в меловое время, в результате на северо-западе Восточно-Европейской равнины в конце мезозоя сформировалась хорошо выраженная полигенетическая поверхность выравнивания.

Самостоятельный геоморфологический цикл выделяется также в течение палеогена. Әтап расчленения включает конец мела, палеоцен и, вероятно, ранний эощен. В это время сформировалась система палеогеновых долин глубиной до 40-60 м, фрагменты которой известны в районе Рославля и пос. Ершичи Смоленской области, Гомеля, Қлимовичей и в других местах (Исаченков, 1975). Основной этап выполаживания связан с эоценовой (киевской) и олигоценовой (харьковской) 
трансгрессиями (Маныкин, 1973). Во время максимума эоценовой трансгрессии море затопило южную часть Литвы и Белоруссии, где на обширных проспранствах накапливались мелкозернистые и тонкозернистые кварцево-глауконитовые пески, местами алевриты, глины и глинисто-карбонатные осадки. В прибрежных частях отлагались хорошо сортированные мелкозернистые кварцевые пески. За пределами морского бассейна происходило выполаживание поверхности путем заполнения аллювиальными и делювиально-аллювиальными осадками древних долин и понижение междуречий процессами денудации. В приморской части выполаживание поверхности сопровождалось ингрессией моря по крупным долинам, о чем свидетельствует наличие в погребенных долинах зеленовато-серых песков с глауконитом (Рославль). На междуречьях в это время сформировались коры выветривания, обнаруженные в Белоруссии и Смоленской области (Карта поверхностей..., 1971; Исаченков, 1964). Таким образом, в конце палеогена на северозападе Восточно-Европейской равнины сформировалась полигенетическая поверхность выветривания, представленная в южной части морской аккумулятивной, в средней - денудационно-аккумулятивной и в северной - денудационной равнинами.

С крупным геоморфологическим щитом связано формирование миоценовой поверхности выравнивания. В Южной Белоруссии поверхность выравнивания сложена отложениями полтавской серии, представленными серыми и светло-серыми плохо сортированными песками, темносерыми и серыми глинами и алевритами с прослоями и линзами бурого угля (Геология СССР, 1971). Мощность полтавских отложений обычно менее $10-15$, местами 20-40 и только в крупных депрессиях подстилающей поверхности достигает $70-80$ м. Формирование их происходило в континентальных условиях и связано с накоплением аллювиальных, озерно-аллювиальных, озерно-болотных и делювиальных осадков в древних долинах и на пониженных участках междуречий. Возраст полтавских отложений определяется от позднего олигоцена до среднего плиоцена, однако основная часть толщи накопилась, вероятно, в ореднем миоцене. Все эти данные свидетельствуют о том, что в течение позднего олигоцена и миоцена выделился полный геоморфологический цикл, завершившийся формированием полигенетической поверхности выравнивания. В Южной Прибалтике и Белоруссии в это время располагались денудационно-аккумулятивная, в остальной части северо-запада - денудационная равнины.

Плиоценовая поверхность выравнивания развита преимущественно на Балтийской ступени, на остальной территории северо-запада Русской равнины сформировалась, вероятно, только поверхность врезания (Можаев, 1973). Распространение дочетвертичных поверхностей выравнивания показано на схеме, составленной по исходным фактическим данным с учетом литературных материалов (Карта поверхностей..., 1971; Исаченков, 1964; Можаев, 1973; Маныкин, 1973). Обращает внимание, что наиболее широко распространены на северо-западе палеогеновая и миоценовая поверхности. При этом палеогеновая поверхность распространена преимущественно на Центрально-Русской, а миоценовая на Белорусско-Прибалтийской ступенях. Первоначально палеогеновая поверхность была распространена, вероятно, на всей территории северо-запада и центра Восточно-Европейской равнины, однако в дальнейшем в Прибалтике, Белоруссии и на северо-западе РСФСР она подвергалась значительной денудации при формировании миоценового уровня и сохранилась здесь только в виде останцев. В Южной Прибалтике и Белоруссии аккумулятивная миоценовая поверхность накладывается на палеогеновую, находящуюся в погребенном состоянии.

Убедительных данных для выделения на современной поверхности 
дочетвертичных пород мезозойского уровня на северо-западе равнины в настоящее время нет. В погребенном состоянии, под отложениями палеогена и неогена, мезозойская поверхность выравнивания сохранилась в Южной Прибалтике и Белоруссии. На остальной территории она была денудирована (или местами вошла в состав) при формировании палеогенового и миоценового уровней.

Особого внимания на рассматриваемой территории заслуживает проблема экзарационного воздействия плейстоценовых ледников на дочетвертичную поверхность. Наиболее достоверный вывод о величине экзарации можно сделать на основании анализа баланса вещества с учетом объема и состава плейстоценовых отложений (Исаченков, 1981). В результате произведенных расчетов было установлено, что объем дочетвертичных пород, подвергшихся экзарации в северозападной части Русской равнины, составляет 22000 км $^{3}$, что соответствует понижению дочетвертичной поверхности в среднем на 40 м. В зависимости от палеогляциологической зональности в древнеледниковой области отмечалась концентрическая зональность процессов экзарации и аккумуляции (Асеев, 1974). Северная часть рассматриваемой территории (Эстония, Латвия, северо-запад РСФСР) находилась в зоне преимущественной экзарации, южная - в зоне аккумуляции. Понижение поверхности дочетвертичных пород под воздействием экзарации достигает в северной части $60-80$, в южной 15-20 м (Исаченков, 1981; Асеев, 1974; Маккавеев, 1975; Матвеев, 1976). Все это свидетельствует, что в зоне преимущественной экзарации доледниковый рельеф в плейстоцене был сильно преобразован и встречающиеся здесь на поверхности дочетвертичных пород разновысотные участки не всегда являются древними поверхностями выравнивания и могут иметь различное, в том числе экзарационное, происхождение. Учитывая среднюю высоту Прибалтийской низменности (абсолютные отметки 45 м) и величину плейстоценовой экзарации (60 м), можно предположить, что реконструированная миоценовая поверхность выравнивания в зоне преимущественной экзарации должна иметь абсолютные отметки в среднем около $100 \mathrm{~m}$.

\section{Выводы}

В течение мезокайнозоя территория северо-запада Восточно-Европейской равнины имела тенденцию к поднятию, вследствие чего здесь сформировалась лестница разновысотных поверхностей выравнивания. Тенденция к поднятию первоначально (в мезозое) проявилась на участках, прилежащих к Балтийскому щиту (Северная Прибалтика, северозапад РСФСР), затем - в Центральной России и Северной Белоруссии (палеоген, миоцен) и на заключительном этапе (плиоцен, плейстоцен) - в Южной Прибалтике и Белоруссии. Соответственно, зона рас пространения денудационных пластовых равнин расширилась, аккумулятивных - сократилась.

На общее поднятие накладывались тектонические дифференциальные движения субмеридионального и диагонального (преимущественно северо-западного) простираний. Поднятия наиболее четко проявились на Центрально-Русской, опускания - на Балтийской ступенях. В результате, палеогеновая и миоценовая поверхности выравнивания имеют в настоящее время общий наклон не с севера на юг, как это было первоначально, а с востока на запад. Наиболее заметно деформацня поверхностей выравнивания проявилась в зонах Валдайско-Днепровского и Балтийского макроскатов, которые можно рассматривать как новейшие геофлексуры, в различной степени преобразованные денудационными процессами. Морфологическому обоснованию новейших гео. флексур способствовал также литологический фактор. 
В связи с зональным распространением процессов экзарации и аккумуляции в древнеледниковой области более благоприятные условия для сохранения дочетвертичных поверхностей выравнивания и связанного с ними комплекса полезных ископаемых имелись в центральной части ледникового щита (зона слабо выраженной экзарации и аккумуляции - Фенноскандия) и по его периферии (зона преимущественной аккумуляции) в Южной Белоруссии и по левобережью Верхнего и Среднего Поднепровья.

\section{ЛИТЕРАТ У РА}

Асеев А. А. Древние материковые оледенения Европы. М., 1974.

Геология СССР, III-IV. M., 1971.

Горелов С. K. Основные закономерности и этапы развития поверхностей выравнивания и кор выветривания на территорин СССР. М., 1974

Даньщин В. М. Доюрский рельеф в связи с условиями отложения юрских осадков в центральных и южных частях Московской губерния. - Вестник геолог. ком., 1927, № $1,10$.

Исаченков В. А. О дочетвертичных поверхностях выравнивания в бассейне верхнего Днепра. - В кн.: Проблемы поверхностей выравнивания. М., 1964, 119-124. Нсаченков B. А. Формирование рельефа северо-запада Русской равнины. М., 1975. (Автореф. док. дис.)

Исаченков B. A. Происхождение крупных форм рельефа северо-запада Русской равнины. - Геоморфология, 1981, № 1, 14-23.

Карта поверхностей выравнивания и кор выветривания СССР. Л., 1971.

Маккавеев $A . H$. Опыт количественной оценки рельефообразующей роли древних ледников на северо-западе Европейской части СССР. - Геоморфология, 1975, № $2,44-50$.

Маныкин С. С. Палеоген Белорусоии. Минск, 1973.

Матвеев А. В. Ледниковая формация антропогена Белоруссии. Минск, 1976.

Мещеряков Ю. А. Структурная геоморфология равнинных стран. М., 1965.

Можаев Б. Н. Новейшая тектоника северо-запада Русской равнины. Л., 1973.

Погуляев Д. И. Геология и полезные ископаемые Смоленской области. Смоленск, 1955.

Шляупа А. Н. Доледниковые поверхности выравнивания Южной Прибалтики. В кн.: Поверхности выравнивания. М., 1973, 251-256.

Псковский педагогический институт

Поступила в редакцию 4/VI 1982

\section{ISSATSENKOV}

\section{IDA-EUROOPA TASANDIKU LOODEOSA KVATERNAARIEELSED} KULUTUSPINNAD

Mattunud kulutuspindade ja nendega rööbistatavate setete analüüs vōimaldab IdaEuroopa tasandiku loodeosas eristada polügeneetilisi hilismesosoikumi, paleogeeni, miotseeni ja pliotseeni kulutuspindu. Andmed nende kōrgussuhete ning deformatsiooni kohta lubavad väita, et kesk- ja uusaegkonnas Ida-Euroopa tasandiku loodeosa kerkis. Kerkimine algas Balti kilbi loodepoolsetelt äärealadelt ning levis Ida-Euroopa tasandiku kesk- ja lääneossa.

\section{ISACHENKOV}

\section{PENEPLAINS IN THE NORTH-WESTERN PART OF THE EAST-EUROPEAN PRE-QUATERNARY PLAIN}

The palaeogeomorphological analysis of the peneplains and their correlation with deposits of the East-European Plain enables to differentiate Late Mesozoic, Paleogene, Miocene and Pliocene peneplains. The relative heights and the character of tectonical deformation of these peneplains make it possible to state that the East-European Plain had a tendency to rise in its north-western part, in the Mesozoic-Kainozoic era. That process started in the border areas of the Baltic Shield and spread over to the central and western regions of the East-European Plain. 